\title{
ORIGINAL \\ PREVALENCE OF HBV, HCV AND HIV IN BLOOD DONORS AT LIAQUETPUR
}

\author{
DR. MUHAMMAD AYUB KHAN, MBBS, M. Phil. \\ Assistant Professor Pathology \\ Quid-e-Azam Medical College Bahawalpur \\ DR. ABDUL REHMAN, MBBS, DCH, FCPS \\ Consultant Paediatrician, \\ Tehsil Headquarter Hospital Liaquetpur
DR. MUHAMMAD ASHRAF, MBBS
Associate Professor Biochemistry
Punjab Medical College Faisalabad

\author{
Dr. Muhammad Ashraf, PhD (UK) \\ Associate Professor Pharmacy \\ IUB Bahawalpur \\ Dr Azam Ali \\ Lecturer Biochemistry \\ K E M C Lahore \\ Dr Allah Ditta \\ Assistant Professor of Pathology \\ PGMI Lahore
}

\begin{abstract}
Objective: To know the prevalence of hepatitis B, hepatitis C and HIV. Design: Observational cross sectional study. Setting: Blood Transfusion Center Tehsil Headquarter Hospital Liaquetpur. Subjects and Methods: The data of blood donors from 2001 to 2003. Results: Total blood donors studied were 1426. The prevalence for hepatitis B was 5.96\% (CL 4.84\%-7.32\%) It was $0.07 \%$ (CL <0.01\% - 0.44\%) for HCV and zero for HIV. The prevalence of HBV in males was 6.03\% (CL 4.87\%-7.45\%) while 5.05\% (CL 1.91\%-11.63\%) in females $(p=0.6917)$. The prevalence in $17-20$ years age group was $6.4 \%$ (CL 3.92\%-10.23\%), 5.81\% (CL 4.6\%-7.33\%) in 21-40 years age group and in 41-60 years age group it was 4.35\% (CL 1.33\%-28.19\%) [p=0.9029]. Conclusion: Hepatitis $B$ is common, hepatitis $C$ is an uncommon health problem while HIV is not present in this area.
\end{abstract}

Key Words: $\quad$ Hepatitis B, hepatitis C, HIV, blood donors, prevalence

\section{INTRODUCTION}

The infections caused by hepatitis $B$ and $C$ viruses and the acquired immune deficiency syndrome (HIV) are not curable with the latest available treatment. All the three infections have the same mode of transmissions. The effective vaccine is available only against hepatitis $B$. All the three diseases may run a chronic course causing financial drain of the family and can result in the death of the sufferer. The chronicity of Hepatitis $B$ and $C$ results in an increased risk of cirrhosis, hepatocellular carcinoma and chronic carrier state. Hepatitis B and C are endemic in most parts of the developing countries while HIV is spreading as an epidemic. These infections are preventable mainly by health education, safe sex, precautions in blood transfusions and the use of disposable syringes and razors etc. The screening tests 
used for these infections are not $100 \%$ sensitive or specific ${ }^{1,2}$. The purpose of this study is to know the prevalence of HBV, HCV and HIV.

\section{SUBJECTS AND METHODS}

This is an observational cross sectional study. There is routine screening for hepatitis $B$, hepatitis $C$ and HIV at Blood Transfusion Center Tehsil Headquarter Hospital, Liaquetpur. The data of blood donors from January 2001 to December 2003 were collected from the record of Blood Transfusion Center and analyzed. Exclusion criterion was age less than 17 and above 60 years.

Graph Pad software computer program was used for statistical calculations. 95\% confidence interval was taken to define normal range. Chi Square test was applied where needed. $P$ value less than 0.05 was taken as significant.

\section{RESULTS}

Total donors studied were 1426. Table-I shows the overall prevalence of hepatitis $B$ as well as prevalence in males and females donors. The difference of prevalence in males and females was statistically insignificant $(p=0.6917)$. Table-II shows the prevalence of hepatitis $B$ at different age groups but the difference was insignificant $(p=0.9029)$. There was one donor positive for hepatitis $\mathrm{C}$ giving prevalence of $0.07 \%$ (CL $<0.01 \%$ $0.44 \%$ ) and none was positive for HIV.

\begin{tabular}{|c|c|c|c|c|}
\hline \multicolumn{5}{|c|}{ Table I. Prevalence of Hepatitis B } \\
\hline Sex & Total donors & positive cases & Prevalence (\%) & Confidence limit (95\%) \\
\hline Male & 1327 & 80 & 6.03 & $4.87 \%-7.45 \%$ \\
\hline Female & 99 & 5 & 5.05 & $1.91 \%-11.63 \%$ \\
\hline Total & 1426 & 85 & 5.96 & $4.84 \%-7.32 \%$ \\
\hline
\end{tabular}

\begin{tabular}{|c|c|c|c|c|}
\hline \multicolumn{5}{|c|}{ TABLE II. Prevalence of Hepatitis B at different age groups } \\
\hline Age group (years) & Total donors & Positive cases & Prevalence (\%) & Confidence limits (95\%) \\
\hline $17-20$ & 250 & 16 & 6.4 & $3.92 \%-10.23 \%$ \\
\hline $21-40$ & 1153 & 67 & 5.81 & $4.6 \%-7.33 \%$ \\
\hline $41-60$ & 23 & 2 & 8.70 & $1.33 \%-28.19 \%$ \\
\hline
\end{tabular}

\section{DISCUSSION}

The prevalence rate for hepatitis B was $5.96 \%(\mathrm{CL}$ 4.84\%-7.32\%) in this study. Most of the studies, like this, are based on screening of donors at blood banks. Mumtaz et $\mathrm{al}^{3}$ and Ryas et al ${ }^{4}$ described the prevalence rate of hepatitis $B$ as $5.86 \%$ and $6.4 \%$ respectively while the other studies $5,6,7,8,9,10,11,12$ in Pakistan gave prevalence rate less than $3.54 \%$. An other study conducted at Lahore ${ }^{13}$ showed $2.3 \%$ mothers and $3.35 \%$ children were positive for HBsAg. The health care workers and medical students at Lahore showed a carrier rate of $6.3 \%$ for hepatitis $B^{14}$. Qasmi et $a^{15}$ reported $3 \%$ individuals of Karachi were positive for HBV. Aziz et al ${ }^{16}$ showed the prevalence $2.4 \%$ for HBsAg. Review of literature in India showed the prevalence of HBV carriers was between $1 \%$ and $2 \%{ }^{17}$. The prevalence of HCV and B infections was not uniform throughout India ${ }^{18,19}$. The prevalence of hepatitis $B$ in blood donors was as high as $8.1 \%$ in Malawi $^{20}$ and $9.3 \%$ in Brazil ${ }^{21}$. The studies in Georgia ${ }^{22}$ and in Saudi Arabia $^{23}$ showed the prevalence rate of $4.1 \%$ and $1.5 \%$ respectively. In this study Hepatitis B was present more in the age group of 40 to 60 years, 
which was not statistically significant. Majeed et $\mathrm{al}^{24}$ also described the same pattern.

The prevalence rate for hepatitis C was $0.07 \%$ in this study, which is less than any other area of Pakistan. The studies $3,45,7,8,9,12,25,26,27$ done on blood donors in Pakistan showed prevalence ranging from $0.82 \%$ to $6.21 \%$. In Karachi $5-6 \%$ adults were positive for $\mathrm{HCV}^{16}$. The prevalence of hepatitis $\mathrm{C}$ was $7.3 \%$ in Georgia ${ }^{22}, 6.8 \%$ in Malawi $^{20}, 1 \%$ in Brazil ${ }^{21}, 0.4 \%$ in Saudi Arabia ${ }^{23}$ and 0.370 in Singapore ${ }^{28}$. Most European countries reported a prevalence of $\mathrm{HCV}$ in the general population from $0.5 \%$ to $2 \%{ }^{29,30}$. Anti-HCV was found in $2.2 \%$ blood donors in Lithuania $^{31}, 20 \%$ in Egypt and more than 5\% in some communities of Italy ${ }^{32}$. Seroprevalence of HCV among hospital based general population in India was $1.57 \%$ $4.8 \%{ }^{33,34}$.

There was not a single case positive for HIV in this study. Other studies done on blood donors in Pakistan also gave a very low prevalence of HIV. Sheikh et $\mathrm{al}^{35}$ gave prevalence rate of $0.22 \%$ while Asif et $a^{15}$ gave $0.25 \%$ in replacement donors. Other studies ${ }^{3,7,8,10,36}$ gave prevalence less than $0.01 \%$ to zero. In Karachi none of person studied had antibodies to $\mathrm{HIV}^{16}$. Candotti et al ${ }^{20}$ described HIV prevalence rate in blood donors $10.7 \%$ in Malawi, Treitinger et $\mathrm{al}^{21}$ described $0.6 \%$ in Brazil and El$\mathrm{Hazmi}^{23}$ zero in Saudi Arabia. The sero-prevalence rates of HIV among males and females from general population were $4.3 \%$ and $2 \%$, and from blood bank donors were $0.14 \%$ and $0 \%$ in India ${ }^{37}$.

\section{REFERENCES}

1. Viswanathan C. Are our donors safe? Indian J Pediatr 2001; 68: 69-75.

2. Stramer SL, Glynn SA, Klein man SH, Strong DM, Caglioti S, Wright DJ, et al. Detection of HIV-1 and HCV Infections among Antibody-Negative Blood Donors by Nucleic Acid-Amplification Testing. New Eng J Med $2004 ; 351 ; 760-68$.

3. Mumtaz S, Rehman MU, Muzaffar M, Hassan MU, Iqbal W. Frequency of seropositive blood donors for hepatitis $B, C$ and HIV viruses in railway hospital. Rawalpindi. Pakistan J Med Res 2002; 41: 51-3.
4. Ryas M, Hussain T, Bhatti FA, Ahmed F, Tariq WZ Khattak MF. Epidemiology of Hepatitis C Virus Infection in Blood Donors in Northern Pakistan. J Rawal Med Coll 2001; 5: 56-9.

5. Asif N, Khokhar N, llahi F. Sero-prevalence of HBV, HCV and HIV infection among voluntary non remunerated and replacement donors Northern Pakistan. Pak J Med Sci 2004; 20: 24-8.

6. Ahmed F, Shah SH, Tariq M, Khan JA. Prevalence of hepatitis $B$ carrier and HIV in healthy blood donors at Ayub Teaching Hospital. Pak J Med Res 2000; 39: 91-2.

7. Mujeeb A, Aamir K, Mehmood K. Sero-prevalence of HBV, HCV and HIV infections among college going first time voluntary blood donors. J Pak Med Assoc 2000; 50: 269-70.

8. Khattak M F, Salamat N, Bhatti F A, Qureshi T Z. Seroprevalence of hepatitis $B, C$ and HIV in blood donors in northern Pakistan. J Pak Med Assoc 2002; 52: 398402.

9. Ali N, Khattak J, Anwar M, Tariq WUZ, Nadeem M, Irfan $M$, et al. Prevalence of hepatitis $B$ surface antigen and hepatitis $\mathbf{C}$ antibodies in young healthy adults. Pakistan J Pathol 2002; 13(2): 3-6.

10. Rahman MU, Akhtar GN, Lodhi Y. Transfusion transmitted HIV and HBV infections in Punjab, Pakistan. Pak J Med Sci 2002; 18: 18-25.

11. Ahmed M. Hepatitis B surface Antigen study in Professional and Volunteer Blood Donors. Ann Abbasi Shaheed Hosp Karachi Med Dent Coll 2001; 6: 304-6.

12. Khokhar N, Gill ML, Malik GJ. General seroprevalence of hepatitis $\mathbf{c}$ and hepatitis b virus infections in population. J Coll Physicians Surg Pak 2004; 14: 208-10.

13. Khan HI. A study of seroprevalence of hepatitis $B$ and C in mothers and children in Lahore. Pak Ped J 1996; 20:163-6

14. Khan GM, Malik MN, Rana K, Fayyaz A. Profile of Hepatitis B Surface Antigen Positivity in Health Care Personnel. Mother \& Child 1996; 34:135-8.

15. Qasmi SA, Aqeel S, Ahmed M, Alam SI, Ahmad A. Detection of Hepatitis $B$ Viruses in Normal Individuals of Karachi J Coll Physicians. Surg Pak 2000; 10: 467-9. 
16. Aziz S, Memon A, Tily HI, Rasheed K, Jehangir K, Quraishy MS. Prevalence of HIV, Hepatitis B and C amongst Health Workers of Civil Hospital Karachi. J Pak Med Assoc 2002; 52: 92-4.

17. Lodha R, Jain Y, Anand K, Kabra SK, Pandav CS. Hepatitis B in India: A review of disease epidemiology. Indian Pediatr 2001; 38: 349-71.

18. Dharmadhikari CA, Kulkarani RD, Kulkarani V, Udgaonkar, Pawar SG. Incidence of hepatitis B surface antigen in liver diseases and voluntary blood donors. J Indian Med Assoc 1990; 88: 73-75.

19. Abraham $\mathrm{P}$, John J. Hepatitis $\mathrm{C}$-a review with particular reference to the Indian Scenario. Indian J Med Microbiol $1995 ; 14: 5-14$

20. Candotti D, Mundy C, Kadewele G, Nkhoma W, Bates I, Allain JP. Serological and molecular screening for viruses in blood donors from Ntcheu, Malawi: high prevalence of HIV-1 subtype $C$ and of markers of hepatitis B and C viruses. J Med Virol 2001; 65: 1-5.

21. Treitinger A, Spada C, Ferreira LA, Neto MS, Reis M, Verdi JC, et al. Hepatitis $B$ and hepatitis $C$ prevalence among blood donors and HIV-1 infected patients in Florian $\tilde{A}^{3}$ polis-Brazil. Braz J Infect Dis 2000; 4: 192-6.

22. Butsashvili M, Tsertsvadze T, McNutt LA, Kamkamidze G Gvetadze R, Badridze. Prevalence of hepatitis B, hepatitis C, syphilis and HIV in Georgian blood donors. Eur J Epidemiol 2001; 17: 93-5.

23. El-Hazmi MM. Prevalence of HBV, HCV, HIV-1, 2 and HTLV-I/Il infections among blood donors in a teaching hospital in the Central region of Saudi Arabia. Saudi Med J 2004; 5: 6-33.

24. Majeed A, Qayyum A. Presence of hepatitis-B virus in healthy donors at blood unit Punjab Institute of Cardiology Lahore. Pak Med Res 2000; 39: 111-2.

25. Ali N, Nadeem M, Qamar A, Qureshi AH, Ejaz A. Frequency of Hepatitis $C$ virus antibodies in blood donors in Combined Military Hospital, Quetta. Pak J Med Sci 2003; 19: 41-4.

26. Ahmad S, Gull J, Bano KA, Aftab M, Khokhar MS. Prevalence of Anti Hepatitis $C$ antibodies in healthy blood donors at Services Hospital Lahore. Pakistan Postgrad Med J 2002; 13: 18-20

27. Lone DS, Aman S, Aslam M. Prevalence of Hepatitis C Virus antibody in Blood Donors of Lahore. Biomedica 1999; 15:103-7.

28. Wang JE. Study on the epidemiology of hepatitis C infection among blood donors in Singapore. J Public Health Med 1995; 17: 87-91.

29. Viral Hepatitis Prevention Board. Hepatitis A, B \& C: defining workers at risk. Viral Hepatitis 1995; 3.

30. World Health Organization. Hepatitis C-global prevalence (Update). Weekly Epidemiological Record 1999; 74: 425-427.

31. Lavanchy D, McMahon B. Worldwide prevalence and prevention of hepatitis $C$. In: Liang TJ, Hoofnagle $\mathrm{JH}$, Eds. Hepatitis C. San Diego, Academic Press, 2000:185 202.

32. Ambrozaitis A, Z Agminas KS, Balc lunaite G, Widell A. Hepatitis $C$ in Lithuania: incidence, prevalence, risk factors and viral genotypes. Clin Diagn Virol 1995; $4: 273-84$

33. Bhattacharya S, Badrinath S, Hamide A, Sujatha S. Seroprevalence of hepatitis $C$ virus in a hospital based general population in South India. Indian $\mathrm{J}$ Med Microbiol 2003; 21: 43-45.

34. Mishra S, Chayani N, Sarangi G, Mallick B, Pati SB. Seroprevalence of anti HCV antibody in and around Cuttack, Orissa. Indian J Med Microbiol 2002; 20: 40-41.

35. Sheikh AA, Sheikh AS, Sheikh NS, Shan R, Malik T, Afridi $F$. High frequency of false positive results in HIV screening in Blood Banks. J Ayub Med Coll Abottabad $2004 ; 16$ (1): 28-31.

36. Khokhar O, Malik GJ, Khokhar N. Prevalence of HIV infection in a healthy population in Northern Pakistan. Rawal Med J 2003; 28: 12-6.

37. Rasheed MU, Hemalatharao K. Sero-prevalence of HIV in a hospital based population and blood bank donors in South India. Indian J Med Microbiol 2004; 22: 66 